scien do Zagreb International Review of Economics \& Business, Vol. 24, Special Conference Issue, pp. 95-110, 2021 (C) 2020 Faculty of Economics and Business, University of Zagreb and De Gruyter Open All rights reserved. Printed in Croatia ISSN 1331-5609; UDC: $33+65$

DOI: 10.2478/zireb-2021-0022 CONFERENCE PAPER

\title{
The Strategic Determinants of the Sport Club Performance
}

\author{
Igor Ivašković*
}

\begin{abstract}
This article aims to disclose the role of strategic factors in the context of a sport club performance. We used 73 basketball clubs from four countries and tested the relationships between four segments of variables (grouped into: a) environmental factors' set, $b$ ) strategic factors' set, c) human resource management (HRM) factors' set, and d) behavioral factors' set) and two different aspects of organizational performance: 1) top-sport-financial and 2) recreational-non-financial performance. The conduction of multiple regression analyses resulted with disclosure of significant direct effect of the strategic factor on both aspects of the sport clubs performance. The results offer explanation how the strategic planning enhances the performance. Better results are achieved by the clubs that pursue specific organizational goals linked to only one aspect of performance. While the theoretical contribution reflects through the evaluation of the importance of different sets of organizational performance factors, from the practical perspective tis study discloses complementary organizational objectives and those organizational aims which are, from an aspect of sport club performance, in contradiction with each other.
\end{abstract}

Keywords: strategy; organizational objectives; performance, sport clubs

JEL Classification: Z20, Z23, Z29

\section{Introduction}

Determination of the strategic performance factors is non-profit sports clubs is a very complex process, due to the fact of wide spectrum of potential organizational purposes of such organizations (Ivašković, 2018). Unlike in the case of profit-oriented professional clubs (Barros and Santos, 2003; Bosca et al, 2009; Espitia-Escuer and Garcia-Cebrian, 2006; Espitia-Escuer and Garcia-Cebrian, 2010), sport literature evidently lacks research in the field of non-profit sport clubs performance. More-

\footnotetext{
* Igor Ivašković is Assistant Professor at School of Economics and Business, University of Ljubljana, Kardeljeva ploščad 17, SI-1000, Slovenia.
} 
over, the vast majority of sport clubs' performance studies was conducted in the field of football (Andreff, 2007; Guzman and Morrow, 2007; Haas, 2003a; Haas, 2003b; Haas, Kocher and Sutter, 2004; Barros and Garcia-del -Barrio, 2011) and much less in other sports fields. The latter however have been mostly carried out among North American sport clubs (Kikulis, Slack and Hinigins 1992; Slack and Hinings, 1994; Stevens and Slack, 1998; Slack, 1997), while studies among European non-profit sports clubs are very rare. Also, the majority sport management scholars dealt with the win ratio as the only performance indicator, while couple of authors evaluated the market performance of sport clubs (Garcia-Sanchez, 2007). The purpose of this article, therefore, is to fill this gap in the literature by evaluating the importance of strategic performance factors of non-profit sports clubs from transitional European countries. The ambition of this paper is to fill this gap in scientific literature by analyzing the importance of the performance factors of sports clubs operating in a transition-non-profit context, where sport organizations have numerous specifics (Ivašković, 2015, pp. 66-67). This type of research is not interesting only due to its methodological complexity, demanded by a specific nature of predominantly service organizations with very dynamic organizational processes, but is also very important for understanding the post-transitional context in ex-communist European countries. First, we develop and explain two aspects of the organizational performance, and then we explore the impact of various factors on both of them. In this setting we were especially interested in the role of strategic planning, where we tried to disclose pairs of organizational aims which could be in contradiction with each other from an aspect of an overall organizational performance.

\section{Research Model}

There are numerous potential factors which might influence the final organizational outcome. Of course, it is never possible to measure all of them at once. However, the theory of management has been enriched in recent decades with plethora of models that suggest how to deal with identification of performance factors. One of the most recognized Wright and McMahan's (1992) five set model is in line with line with the thesis that an analysis of the performance in a particular industry has to begin with identification of factors from wider institutional context and then has to continue through strategic aspects towards business practices on day to day basis. We decided to follow that particular model of research, which was then modified for the particular study among the non-profit sport clubs in line with Ivašković's (2015, 70-75) recommendations. We therefore measured following four sets of variables:

1) Strategic focus set - the key decisions of club's management (hierarchy of organizational objectives, resolution of three strategic dilemmas etc.). 
2) Environmental set that represents the institutional framework within which the organizations operate.

3) Human resource management (HRM) practices and human capital set represent practices and a value of knowledge, skills, competencies and acquaintances of members of particular organization.

4) Feelings and behavioral patterns set (we measured the degree of trust among club members, the team cohesion, work-engagement of athletes etc.).

The strategic factors' set takes the central position in this particular study. It consisted of 19 variables. First, we included three key strategic dilemmas: a) the issue of the cutting-costs ambition versus the desire for organizational growth, b) pursuing top sport results versus the ambition of the local environment and community development, and c) quick results and consequently greater risks versus the focus on risk reduction and work in the long run (Ivašković, 2019a). The way of resolving these dilemmas depends on the hierarchy of organizational goals. For the purpose of this research we followed the Kaplan's (2001) recommendation that the performance evaluation of non-profit organizations has to be multidimensional. The list of non-profit clubs goals was made with the help of 12 managers with at least five years of experience on leadership positions in sport clubs. Each of them wrote down five purposes of sport clubs' existence. Additionally, they also identified up to five objectives that, in their experience, clubs are actually pursuing. After that we combined similar organizational aims listed by different experts and obtained the final list as follows: 1) the municipality promotion, 2) the development of infrastructure in the local community, 3 ) the promotion of private sponsors, 4) increasing the number of spectators at home matches, 5) development of athletes for national selections, 6) generation of profit (surplus of incomes over expenses), 7) development of top athletes, 8) sport results of the first team, 9) budget growth, 10) increasing athletes' market value, 11) reducing the costs, 12) increasing the number of organizational members, 13) involvement of the local population in the club's activities, 14) encouraging the local population to do sports, and 15) sport results of junior teams. Our respondents had to assess the importance of each of these 15 organizational goals for their club on a 7-point Likert scale, anchored at the extremes (1) "not important at all" and (7) "the most important of all listed goals."

Environmental set of variables examines how the organizational performance is influenced by the rank of competition on which a particular sports club competes (in national and international league competitions). The broader determinants of the environment depend on both; the amount of the club's annual budget for the particular season, as well as on the sources of funding and the ratio of public and private resources. Indirectly, the quality of the infrastructure and capacity of the home hall in which the club plays home games depend indirectly on the environment, since they are usually built according to the size of the population in the local commu- 
nity. Within the institutional environment stakeholders represent one of the key issues. The concept of stakeholders implies an endless list of potential interest groups and individuals which have to be defined on a case-by-case basis. For the purpose of this research, the list wa alsos drawn up with the help of 12 professionals, each with at least five years of professional experience working in management positions at non-profit basketball clubs. After explaining the concept of stakeholders and the stakeholder process, each member of this work group was asked to make a list of the most influential stakeholders or interested individuals in terms of their influence on the clubs' strategy. The final list of 10 stakeholders was the result of grouping similar ones and deleting those groups or individuals that were listed several times: 1) volunteers (include all club members who are not employed in the club and do their work free of charge), 2) professionals (all club members who have an employment contract excluding athletes and coaches), 3) athletes and coaches, 4) private sponsors (organizations that provide funds to the club in exchange for advertising, and at the same time they are not predominantly state or municipally owned), 5) the state, 6) the municipal authorities, 7) the local community (residents that live in the municipality where the club is registered), 8) media, 9) national sport federation and sport clubs in the same competitions, 10) the general public. In total, the impact of 18 variables was analyzed in this segment. We tried to obtain objective data as much as possible and the estimations given by members of each club managerial staff. For example, assessment of the stakeholders' impact was made on a seven-point Likert scale (1 "the group has no influence on the strategy"; 7 - "the group has the greatest influence among all stakeholders").

Sports clubs are predominantly service organizations, so human resource management (HRM) is of high importance in these organizations, which have numerous HRM specifics (Ivašković, 2018):

- Athletes have a shorter working period, which accelerates the whole HRM and business cycles.

- European sport clubs have a two-part organizational structure, namely a part related to administrative and managerial staff which does not differ essentially from other organizations, and a section that relates to athletes and has its own specifics.

- Athletes' market is very developed and contains numerous agencies that represent athletes' interests.

- Sport results and athletes' values are easier to objectify due to easier measurement of past achievements.

- HRM specific of European sport clubs is also the fact that those organizations might obtain athletes through their own education system.

- The duality of the organizational structure stems from the fact that many of the clubs have a professionalized part of the organization (this refers to the activities of a first team), while the part of the club that involves youth usually operates on amateur principles. 
A total of 65 HRM variables were included in this study, including the following:

- The influence of organizational bodies and members, and stakeholders on the design of HRM process.

- The average retention period of the management and administrative staff at the club.

- The annual budget for professional basketball contracts and the market value of sports personnel.

- The proportion of club staff with professional status (and the extent to which club members volunteer for the work of the organization) and the proportion of club budget devoted to the professional part of the club.

- Sources of recruitment (local, national, international).

- The degree of formalization of the HRM process.

- The fluctuation in the club and the educational structure of the administrative and management staff.

Finally, in the light of the literature in the field of sports management, the intangible factors that relate to human relations and to the degree of individual's engagement in the pursuit of organizational goals are crucial to the success of sports clubs. In this context, we included 63 variables that relate to the behavior and feelings of members of observed clubs. Above all, we focused on the level of trust in the club (the relationships in the triangle of athlete - coach - top management), the level of team cohesiveness, and the level of work engagement that reflects the willingness of individuals to sacrifice their goals for the good of organization. Data from the third set of variables were obtained at three levels, namely from the managerial staff, coaches and athletes. Cohesiveness was measured using Carron, Widmeyer and Brawley's (1985) Group Environment Questionnaire; work engagement was measured using Schaufeli, Bakker and Salanova's (2006) Utrecht scale, while trust was measured using Adams, Waldherr and Sartori's (2008) questionnaire, which measures trust using four dimensions (benevolence, integrity, predictability, and competence).

\section{Sport Club Performance}

The performance of non-profit sports clubs cannot be simply reduced to a financial and sports result. For the purpose of this research, the results of a study regarding the identification of different aspects of sports clubs' performance were considered (Ivašković, 2019b). The factorization of performance evaluation regarding achieving 15 different organizational goals, developed for the context of non-profit basketball clubs, show that two basic aspects of performance can be distinguished; namely financially-competitive and non-financial-recreational (Table 1). 
Table 1: Results of factor analysis for importance of organizational aims

\begin{tabular}{|l|c|c|}
\hline \multicolumn{1}{|c|}{ Component } & \multicolumn{2}{c|}{ Factor } \\
\cline { 2 - 3 } & 1 & 2 \\
\hline Promotion of municipality & -.546 & .699 \\
\hline Increasing the number of club members & -.643 & .502 \\
\hline Involvement of local population in the club's activities & -.808 & .420 \\
\hline Encouraging local population to do sports & -.696 & .612 \\
\hline Development of infrastructure in local environment & -.618 & .424 \\
\hline Sport results of junior teams & & .603 \\
\hline Attracting spectators to the matches & .351 & .541 \\
\hline Development of athletes for national selections & .509 & .668 \\
\hline Development of top athletes & .748 & .388 \\
\hline Reducing the costs & .762 & .347 \\
\hline Private sponsor promotion & .725 & \\
\hline Budget growth & .713 & \\
\hline Sport results of first team & .859 & \\
\hline Surplus of revenues over expenses & .859 & \\
\hline Increasing athletes' market value & .857 & \\
\hline
\end{tabular}

Note: The factors explain $66.88 \%$ of the variance.

Source: Ivašković, 2019b, p. 162.

\section{Methodology}

The data collection took place in 2014 and 2015 among basketball clubs from Bosnia and Herzegovina, Croatia, Slovenia, and Serbia. At the time of the study in all four countries there were 249 basketball clubs engaged in national competitions on all quality levels. 73 of them participated in the study, which represents a response rate of $29.3 \%$, and is according to the HRM literature sufficient to carry out the analysis (Pološki-Vokić, 2004; Becker and Huselid, 1998). Among the 73 participating clubs there were 27 first-division clubs, 31 second-division and 15 lower-division clubs. Among the 27 clubs from the first national leagues, nine clubs also participated in the regional ABA (Adriatic Basketball Association) league and other international competitions. We collected data on three organizational levels, namely among athletes (559 athletes were included), head coaches (73), and clubs' presidents (73).

Due to the extensive nature of the survey, we decided to use the multivariate analyzes for data processing. More precisely, the sets of multiple regression analyzes with backward elimination as recommended by Pološki-Vokić (2003). Also, due to the fact that this particular case demands a wider perspective, we additionally performed sets of hierarchical multiple regressions, which enable evaluation of theoretical models that contain several sets of factors. Indeed, hierarchical multiple regression enables gradually adding particular sets of factors and consequently the evaluation of the di- 
rect effect each set has on the outcome (Aron and Aron, 1999; Cohen, 2001). In order to prepare data for multiple regressions, the correlation and factor analyses, as well as the Kruskal-Wallis and t-tests were performed. As the dependent variables two aspects of performance defined by Ivašković (2019b) were used, namely 'financial and competitive' and 'non-financial and recreational' performance. Each data processing started with correlation analysis (and t-test for dichotomous variables), after which all variables that did not statistically significantly correlate with performance variable were eliminated. The Kruskal-Wallis variance analysis test was then performed for the interval variables. Variables that did not reach the statistical significance level at the 0.05 threshold were excluded from further analysis. The individual sets were then analyzed. Factor analysis was performed for each (first for objective relational and then for interval variables of each set). First, we performed multiple regression analyzes with the dependent variable "competitive-financial" performance, and then repeated the procedure in the case of "recreational-non-financial" performance as the dependent variable.

\section{Results}

\section{The Model of Financial-Competitive Performance}

After correlation and Kruskal-Wallis variance analyses individual sets of variables were analyzed. For each set a factor analysis was carried out (first for objective relational and then for interval variables of a particular set). Finally, 13 factors were included in the final regression model with the perception of achieving competitive and financial goals as dependent variable. The hierarchical multiple regression had four phases. We gradually included factors from all four sets of variables, first "environment" (model 1), then "strategic focus" (model 2), "HRM and human capital" (model 3 ), and finally "behavior" (model 4). The obtained results are shown in the Table 2.

Table 2: A summary of the hierarchical multiple regression analysis for the financial-competitive performance

\begin{tabular}{|c|c|c|c|c|c|c|}
\hline \multirow{2}{*}{ Model } & \multirow{2}{*}{$\mathrm{R}$} & \multirow{2}{*}{$\mathrm{R}^{2}$} & \multirow{2}{*}{ Adjusted $\mathrm{R}^{2}$} & \multicolumn{3}{|c|}{ Changes } \\
\cline { 5 - 7 } & & & & Ch. $\mathrm{R}^{2}$ & Ch. $\mathrm{F}$ & Ch. sig. $\mathrm{F}$ \\
\hline 1 & $0.810^{\mathrm{a}}$ & 0.656 & 0.640 & 0.656 & 42.564 & 0.000 \\
\hline 2 & $0.967^{\mathrm{b}}$ & 0.935 & 0.928 & 0.279 & 90.744 & 0.000 \\
\hline 3 & $0.971^{\mathrm{c}}$ & 0.943 & 0.931 & 0.008 & 1.402 & 0.229 \\
\hline 4 & $0.976^{\mathrm{d}}$ & 0.952 & 0.940 & 0.009 & 5.256 & 0.008 \\
\hline
\end{tabular}

All models were statistically significant at $\mathrm{p}<0.001$, and the final model 4 ( $\mathrm{F}=$ $79.050 ; \mathrm{p}=0.000$ ) explained $94.0 \%$ of the variance in the top managers' perceptions 
of the club's financial-competitive performance. We can notice that environmental factors explain $65.6 \%$ of the variance, the strategic focus factors clarify additional $27.9 \%$ variance, while the factors from the HRM and human capital set contributed to clarifying negligible $0.8 \%$ of the variance of the dependent variable. The factors of "behavior" helped to explain slightly more, an additional $0.9 \%$. The hierarchical multiple regression method showed that only four out of the 14 factors statistically significant affected financial-competitive performance at the level of 0.05 , only two at 0.01 , and only one at $\mathrm{p}<0.001$ (Table 3). Accordingly we may conclude that the strategic focus of observed non-profit basketball clubs has the strongest impact on this aspect of organizational performance, namely factors "strategic focus 1 " $(\beta=$ $0.846 ; p=0.000)$ "strategic focus 3" $(\beta=-0.109 ; p=0.008)$. At the same time the HRM factors that were included in this study showed somewhat weaker impact. Only the set of relational HRM and human capital factor $(\beta=0.171 ; p=0.015)$ and factor "behavior 1" set $(\beta=-0.184 ; \mathrm{p}=0.035)$ showed statistically significant impact on this aspect of performance.

Table 3: Coefficients of the final hierarchical multiple regression model for the financial-competitive performance

\begin{tabular}{|l|c|c|c|c|}
\hline \multicolumn{1}{|c|}{ Set of variables } & $\mathrm{B}$ & $\beta$ & $\mathrm{T}$ & $\mathrm{p}$ \\
\hline Constant & 0.007 & & 0.248 & 0.805 \\
\hline Environment relational & -0.084 & -0.083 & -1.333 & 0.188 \\
\hline Environment interval 1 & -0.084 & -0.083 & -0.994 & 0.325 \\
\hline Environment interval 2 & -0.012 & -0.012 & -0.306 & 0.761 \\
\hline Strategic focus 1 & 0.838 & 0.846 & 10.040 & 0.000 \\
\hline Strategic focus 2 & 0.063 & 0.063 & 1.304 & 0.198 \\
\hline Strategic focus 3 & -0.109 & -0.109 & -2.759 & 0.008 \\
\hline HRM relational & 0.222 & 0.171 & 2.510 & 0.015 \\
\hline HRM interval 1 & -0.152 & -0.143 & -1.413 & 0.163 \\
\hline HRM interval 2 & -0.085 & -0.079 & -1.572 & 0.122 \\
\hline HRM interval 3 & 0.030 & 0.028 & 0.635 & 0.528 \\
\hline HRM interval 5 & -0.077 & -0.071 & -1.808 & 0.076 \\
\hline Behavior 1 & -0.189 & -0.184 & -2.159 & 0.035 \\
\hline Behavior 2 & -0.049 & -0.048 & -0.998 & 0.323 \\
\hline
\end{tabular}

Note: A dependent variable - the perception of financial-competitive performance.

In order to increase the reliability and validity of the results obtained with hierarchical multiple regression, we also conducted the method of multiple regression with the so-called backward elimination of input variables recommended by Pološki-Vokić (2003). Through several regression analyses the input variables which did not show statistically significant $(p>0.05)$ impact on dependent variable were gradually eliminated. Finally the following regression model has been obtained: 


$$
y=0,011+0,903 x_{1}-0,065 x_{2}-0,074 x_{3}-0,104 x_{4}
$$

Meaning of the labels:

$\mathrm{y}$ - financial-competitive performance;

$\mathrm{x}_{1}-$ strategic focus 1 ;

$\mathrm{x}_{2}-$ strategic focus 3 ;

$\mathrm{x}_{3}-$ HRM interval 2;

$\mathrm{x}_{4}-$ behavior 1 .

The linear multiple regression model obtained with the method of backward elimination was statistically significant at $\mathrm{p}<0.001(\mathrm{~F}=257.196 ; \mathrm{p}=0.000)$ and explained $94 \%$ of the variance of the dependent variable $\left(\mathrm{R}^{2}=0.940\right.$, adjusted $\mathrm{R}^{2}=$ 0.936), which is relatively high for social studies. This test also showed that only four of the 13 input variables statistically significantly influence the measured perception of the clubs' financial and competitive performance. Interestingly, from the strategic focus and the behavior set the same factors were identified as with previous method, while from the HRM and human capital set different factor was identified to have significant impact. Once again, the strongest impact on the dependent variable had the factor "strategic focus 1 " $(\mathrm{x} 1 \rightarrow \mathrm{t}=24.425 ; \mathrm{p}=0.000 ; \beta=0.912)$, while significantly weaker effects were shown by variables in the factors "strategic focus 3 " (x2 $\rightarrow \mathrm{t}=-2.063 ; \mathrm{p}=0.043 ; \beta=-0.065)$, "HRM interval 2" ( $\mathrm{x} 3 \rightarrow \mathrm{t}=-2.078 ; \mathrm{p}=0.042$; $\beta=-0.068)$ and "behavior 1 " ( $\mathrm{x} 4 \rightarrow \mathrm{t}=-2.506 ; \mathrm{p}=0.015 ; \beta=-0.101)$. Therefore, the results according to this method also confirm that strategic focus factors are of key importance in terms of the impact on the financial-competitive performance of non-profit basketball clubs.

\section{The Model of Non-financial-recreational Performance}

The same procedure as for the previous model was conducted for the non-financial and recreational aspect of performance. Again the Kruskal-Wallis's variance analysis was performed. The variables that did not reach the statistical significance at the 0.05 threshold were excluded from the following analysis. In the next phase for each set a factor analysis was performed, first for relational and then for interval variables.

The final regression model included nine factors. The Table 4 shows results of hierarchical multiple regression in which the sets of variables were gradually included in four steps, firstly the "environment" (model 1), followed by the "strategic focus" (model 2), then the "HRM and human capital" (model 3) and, finally, the "behavior" (model 4). 
Table 4: Summary of hierarchical multiple regression analysis for non-financial-recreational performance

\begin{tabular}{|c|c|c|c|c|c|c|}
\hline \multirow{2}{*}{ Model } & \multirow{2}{*}{$\mathrm{R}$} & \multirow{2}{*}{$\mathrm{R}^{2}$} & \multirow{2}{*}{ Adjusted $\mathrm{R}^{2}$} & \multicolumn{3}{|c|}{ Changes } \\
\cline { 5 - 7 } & & & & $\mathrm{Ch}^{2}$ & Ch. F & Ch. sig. F \\
\hline 1 & $0.060^{\mathrm{a}}$ & 0.004 & -0.010 & 0.004 & 0.254 & 0.616 \\
\hline 2 & $0.696^{\mathrm{b}}$ & 0.485 & 0.462 & 0.481 & 32.187 & 0.000 \\
\hline 3 & $0.795^{\mathrm{c}}$ & 0.631 & 0.598 & 0.147 & 8.760 & 0.229 \\
\hline 4 & $0.800^{\mathrm{d}}$ & 0.640 & 0.589 & 0.009 & 0.504 & 0.681 \\
\hline
\end{tabular}

Results show that the environmental factors explain less than $1 \%$ of the perception of the variance. At the same time, the strategic focus factors seem to play a much larger role, as they explain $48.5 \%$ of the variance of the dependent variable together with the environment. In contrast to the analysis of financial-competitive performance factors, in this case the HRM factors showed a significantly higher impact. Their addition to the regression model enabled the joint explanation of $63.1 \%$ of the variance of the dependent variable, while the behavior factors contributed to explaining only additional $0.9 \%$ of dependent variable's variance. Apart from the first model, all the others were statistically significant. The final model $4(\mathrm{~F}=12.442 ; \mathrm{p}=$ 0.000 ) explained in total $64 \%$ of the variance of this aspect of performance, which is significantly less than in the case of financial-competitive performance model. Moreover, unlike in the case of hierarchical multiple regression for the latter, the same method has in this case showed that only two out of nine factors statistically significant $(\mathrm{p}<0.05)$ influence the perception of non-financial-recreational performance of non-profit basketball clubs. This aspect of performance was influenced stronger by the variables in the factor "strategic focus 2 " $(\beta=0.559 ; p=0.000)$ and factor "HRM interval 1" $(\beta=0.423 ; p=0.000)$. The results are shown in Table 5.

Table 5: Coefficients of the final hierarchical multiple regression model for non-financial-recreational performance

\begin{tabular}{|l|c|c|c|c|}
\hline \multicolumn{1}{|c|}{ Factor } & $\mathrm{B}$ & $\beta$ & $\mathrm{t}$ & $\mathrm{p}$ \\
\hline Constant & 0.027 & & 0.351 & 0.726 \\
\hline Environment & 0.202 & 0.200 & 1.390 & 0.169 \\
\hline Strategic focus1 & 0.037 & 0.037 & 0.330 & 0.743 \\
\hline Strategic focus 2 & 0.556 & 0.559 & 4.696 & 0.000 \\
\hline HRM relational & 0.020 & 0.016 & 0.131 & 0.896 \\
\hline HRM interval 1 & 0.435 & 0.423 & 4.195 & 0.000 \\
\hline HRM interval 2 & 0.133 & 0.130 & 1.267 & 0.210 \\
\hline Behavior 1 & 0.132 & 0.124 & 1.120 & 0.267 \\
\hline Behavior 2 & 0.013 & 0.013 & 0.151 & 0.880 \\
\hline Behavior 3 & 0.018 & 0.017 & 0.158 & 0.875 \\
\hline
\end{tabular}

Note: A dependent variable - the perception of non-financial-recreational performance. 
In order to increase the reliability and validity of results, a multi-regression with the so-called backward elimination of input variables was also used for this case. It resulted in the following regression model:

$$
y=0,026+0,636 x_{1}+0,412 x_{2}
$$

Meaning of the labels:

$\mathrm{y}$ - non-financial-recreational performance;

$\mathrm{x}_{1}$ - factor of strategic focus 2 ;

$\mathrm{x}_{2}-\mathrm{HRM}$ interval factor 1 .

The linear multiple regression model $(\mathrm{F}=57.942 ; \mathrm{p}=0,000)$ explained $62.3 \%$ variance $(\mathrm{R} 2=0.623$; adjusted $\mathrm{R} 2=0.613)$. This confirms the previous finding that the observed factors in this study have greater influence on the financial-competitive performance than on non-financial-recreational. In the case of regression models for the perception of non-financial and recreational performance there were no significant differences between the results of hierarchical and multiple regressions with backwards elimination. The effects on the dependent variable were confirmed by the same factors from the nine included parameters $(\mathrm{x} 1 \rightarrow \mathrm{t}=8.658 ; \mathrm{p}=0.000 ; \beta=0.639$; $\mathrm{x} 2 \rightarrow \mathrm{t}=5.436 ; \mathrm{p}=0.000 ; \beta=0.401)$. This method showed once again that the strategic focus factors are the most important among all observed and have a direct impact on both aspects of performance. However, unlike in the model of financial-competitive performance, the HRM factors were found to have a somewhat greater impact on the non-financial and recreational aspect.

\section{Discussion, Conclusions and Limitations}

Three factors showed statistically significant influence on the financial-competitive performance of sport clubs by both methods. Namely: "strategic focus 1", "strategic focus 3" and "interval behavior factor 1". The factor "strategic focus 1" showed a strong positive influence, while variables from the factor "strategic focus 3 " were found to have weak negative impact on particular aspect of performance. If we break down those factors, we can conclude the following regarding the financial-competitive performance of non-profit basketball clubs:

a) Emphasizing the top sport results in club's strategic documents at the expense of meeting the local community needs increases the organizational chances for better financial and competitive performance. This seems to be the key strategic issue for majority of sports clubs (Kern et al. 2012; Breitbarth and Harris 2008; Ivašković 2015), since sooner or later organizational management has to 
decide whether the club is going strive for local athletes will try to attract better skilled personnel on international markets (Taylor, Doherty, and McGraw, 2008, 28). Clubs from higher ranked competitions and with the ambition of top sport achievements invest their energy and resources exclusively in the latter, which implies a greater likelihood of a top sport results. In this respect, they are discouraged, especially during the economic recession periods, to invest in other spheres of organizational activities. The top sport result ambitions therefore diminish the concerns for the development of the local environment and community.

b) Emphasizing cost-effectiveness at the expense of growth increases the chances for better financial and competitive performance. Cost effectiveness does not necessarily imply cost reductions, but rather an attempt to maximize the utilization of funds available to the organization. Basketball clubs with the ambition of achieving top sport results usually have an organizational structure which enables them to do so. Consequently, there is no excessive desire to increase organization; they rather strive for optimization of organizational processes that take place within the existing structure.

The results of this study suggest the hierarchy of strategic goals significantly affects the financial-competitive performance of observed non-profit basketball clubs. The positive impact on this aspect of performance has the placement of following goals higher in the clubs' hierarchies of objectives: 1) budget growth, 2) generation of the surplus of revenues over expenses, 3) private sponsor promotion, 4) sport results of first team, 5) attracting spectators to home matches, 6) increasing athletes' market value, 7) development of top basketball players, 8) development of athletes for national selections, 9) reducing the costs for club's operations. On the other hand, it seems that focus on meeting the needs of the local environment at the expense of the top sport result, and emphasizing growth at the expense of cost-effectiveness diminish possibilities for success on the financial and sport competitive fields. Consequently, increasing the importance of following goals and integrating them into the organizational strategy reduces the club's potential to achieve top sport and better financial results: 1) promotion of the municipality, 2) involvement of the local population in club's activities, 3) encouraging local population to do sport, and 4) development of sports infrastructure in the local environment.

Both methods showed that beside the strategic focus factors the influence (albeit weak) on competitive and financial performance have also certain variables from the feelings and behavior set. Results show that the competitive and financial performance suffered a negative effect from: 1) athletes' perception of their teammates' benevolence, 2) head coach's perception of the athletes' benevolence, 3) head coach's perception of the club management's benevolence, 4) the perception of the head coach about the competence of the club's management, and 5) the head coach's trust in management. The latter is at first sight somewhat surprising result, which is however 
probably related with a less interferences by top management in the work of the head coach and coaching staff. Thus, it is probably a consequence of professionalization and specialization processes which lead to better sport results. It is also somewhat surprising that the perceptions of athletes' benevolence by their teammates and even by head coach are in negative relation with competitive and financial performance. This however does not imply that we need bad relations within team for a good sport result. It rather indicates that in higher quality teams good relations and mutual trust within team do not derive from the perception of benevolence, but from other sources such as perception of competence etc. It is certainly a surprising finding that from the HRM set not a single factor showed statistically significant impact on competitive-financial performance.

Fewer factors were identified to have a significant impact on the non-financial and recreational aspect of performance. Both methods, hierarchical multiple regression and multiple regression with backward elimination, yielded similar results and identified the same sets of factors, namely the factor of "strategic focus 2" and "HRM interval factor 1". Managements that want to increase this aspect of organizational performance have to emphasize the importance of the following goals: 1) promotion of the municipality, 2) involvement of the local population in the club activities, 3) encouraging local population to do sports, 4) attracting spectators to the home matches, 5) development of athletes for national selections, 6) sport results of junior teams, 7) increasing the number of club members, and 8) the development of sports infrastructure in the local environment. Both multiple regression methods also confirmed that the non-financial-recreational performance is also affected by some HRM variables, namely: 1) the existence of formal rules in contract processes with athletes, 2) the existence of formal rules for performance evaluation, and 3) the influence of the head coach on the financial compensation.

The results of both models evidently show that the final organizational outcome is influenced by all goals, which importance was measured in particular study (Table 6). Nine out of the 15 goals have a positive impact on only one aspect of performance, while they do not affect the other. Seven of these have only a positive impact on the financial-competitive aspect of performance; two (increasing the number of club members and sport results of junior teams) have positive impact on the non-financial and recreational aspect and do not harm financial-competitive performance. The second group is represented by organizational goals that have an ambivalent influence on organizational performance. They positively affect the recreational and non-financial aspect of performance, but negatively affect the financial-competitive aspect. These are: 1) promotion of the municipality, 2) involvement of local population in club's activities, 3) encouraging local population to do sport, and 4) development of infrastructure in local environment. Managers should therefore be aware that some goals are incompatible with others. Thus, their integration into the organization's strategic plans might lead to so called "stuck in the middle" problem and could decrease the 
club's potential for success from both aspects of organizational performance. The third segment is formed of two goals, whose involvement in club strategic plans has a positive impact on both aspects of performance. These are attracting spectators to home matches and development of athletes for national selections. Integrating these goals into the organizational strategic plan should thus be beneficial for professional and amateur clubs, so their involvement in the strategic plans of is certainly recommendable.,

Table 6: The influence of organizational goals' importance on the performance of non-profit basketball clubs

\begin{tabular}{|l|c|c|}
\hline \multirow{2}{*}{ Goal } & \multicolumn{2}{c|}{ Direct impact on performance } \\
\cline { 2 - 3 } & $\begin{array}{c}\text { Financial- } \\
\text { competitive aspect }\end{array}$ & $\begin{array}{c}\text { Non-financial and } \\
\text { recreational aspect }\end{array}$ \\
\hline Sponsors promotion & positive & neutral \\
\hline Generation of the surplus of revenues over expenses & positive & neutral \\
\hline Attracting spectators to home matches & positive & positive \\
\hline Development of top basketball players & positive & neutral \\
\hline Sport results of first team & positive & neutral \\
\hline Development of athletes for national selections & positive & positive \\
\hline Budget growth & positive & neutral \\
\hline Increasing athletes' market value & positive & neutral \\
\hline Reducing the costs & positive & neutral \\
\hline Sport results of junior teams & neutral & positive \\
\hline Promotion of municipality & negative & positive \\
\hline Involvement of local population in club's activities & negative & positive \\
\hline Encouraging local population to do sports & negative & positive \\
\hline Increasing the number of club members & neutral & positive \\
\hline Development of infrastructure in local environment & negative & positive \\
\hline
\end{tabular}

This study may be beneficial for the non-profit sport clubs' managers in the process of strategic planning. Indeed, the results of this study may be used as guidelines for defining clubs' goals. Obviously the hierarchy of strategic goals in basketball clubs can significantly contribute to the organizational performance. Likewise, incorrect setting of priorities can reduce the chances of success. The study has therefore empirically confirmed the existence of direct causal relationships between the strategic focus and organizational performance. On the other hand, it confirms the assumptions regarding complexity of HRM - performance relationship (Purcell et al., 2003; Wright et al., 2005). The results indicate that the link between HRM and human capital on one side and the organizational performance on the other in the context of non-profit basketball clubs is probably indirect. Many factors indeed statistically correlate with organizational performance, but the regression analyses did not reveal the significant HRM impact on any of the two measured performance aspects. This is 
in line with the so called "black box" thesis; there is a space of unknown connections between HRM practices and their consequences on the organizational performance. Therefore, identification of intermediate factors between HRM and performance remains as one of the future key study areas in the field of management.

Finally, the limitations of particular research should be mentioned. First of all, multiple regression methods which were used in this study are not always suitable for testing more complex causal relationships, since they measure only direct relationships between dependent and independent variables. At the same time, factor analyses and other statistical techniques were used in order to reduce the number of variables, which implies the possibility that we have omitted certain variables, which in fact have a direct impact on at least one of two measured aspects of performance. Of course, another limitation is the fact that we could not include all potential performance factors in the study. However, this study represents an important starting point for further studies on non-profit sport clubs' organizational performance factors.

\section{REFERENCES}

Adams, B.D., Waldherr, S., and Sartori, J. (2008). Trust in teams scale. Trust in leaders scale, Manual for Administration and Analyses. Toronto: Department of National Defence. [Online]. Available at: http://www.dtic.mil/dtic/tr/fulltext/u2/a488604.pdf (Accessed: 27 May 2015).

Andreff, W. (2007). French football: A financial crisis rooted in weak governance, Journal of Sports Economics, 8(6), 652-661.

Aron, A., and Aron, E.N. (1999). Statistics for psychology. 2nd edn. Upper Saddle River, NJ: Prentice Hall.

Barros, C.P., and Garcia-del-Barrio, P. (2011). Productivity drivers and market dynamics in the Spanish first football league, Journal of Productivity Analysis, 35, 5-13.

Barros, C.P., and Santos, A. (2003). Productivity in sports organisational training activities: A DEA study, European Journal of Sport Management Quarterly, 3(1), 46-65.

Becker, B.E., and Huselid, M.A. (1998). High performance work systems and firm performance: A synthesis of research and managerial implications. Research in Personnel and Human Resources Journal, 16(1), 53-101.

Bosca, J.E., Liern, V., Martinez, A., and Sala, R. (2009). Increasing offensive or defensive efficiency? An analysis of Italian and Spanish football, International Journal of Management Science, 37, 63-78.

Carron, A.V., Widmeyer, W.N., and Brawley, L.R. (1985). The development of an instrument to assess cohesion in sport teams: the Group Environment Questionnaire, Journal of Sport Psychology, 7(3), 244-266.

Cohen, B.H. (2001). Explaining psychological statistics. 2nd edn. New York: Wiley.

Espitia-Escuer, M., and García-Cebrián, L.I. (2006). Performance in sports teams: Results and potential in the professional soccer league in Spain, Management Decision, 44(8), 1020-1030.

Espitia-Escuer, M., and García-Cebrián, L.I. (2010). Measurement of the efficiency of football teams in the Champions League, Managerial and Decision Economics, 31(6), 373-386.

Garcia-Sanchez, I.M. (2007). Efficiency and effectiveness of Spanish football teams: a three-stageDEA approach, Central European Journal of Operations Research, 15(1), 21-45. 
Guzman, I., and Morrow, S. (2007). Measuring efficiency and productivity in professional football teams: evidence from the English Premier League, Central European Journal of Operations Research, 15(4), 309-328.

Haas, D.J. (2003a). Technical efficiency in the major league soccer, Journal of Sport Economics, 4(3), 203-215.

Haas, D.J. (2003b). Productive efficiency of English football teams - A data envelopment analysis approach, Managerial and Decision Economics, 24(5), 403-410.

Haas, D., Kocher, M., and Sutter, M. (2004). Measuring efficiency of German football teams by data envelopment analysis, Central European Journal of Operations Research, 12(3), 251-268.

Ivašković, I. (2015). Vpliv ravnanja z ljudmi pri delu na uspešnost profesionalnih športnih klubov $z$ nedobičkovno tradicijo - študija košarkarskih klubov v jugovzhodni Evropi. Ljubljana: Faculty of Economics.

Ivašković, I. (2018). Analiza razlik v sistemih ravnanja z ljudmi pri delu v košarkarskih klubih Jugovzhodne Evrope, Šport: revija za teoretična in praktična vprašanja športa, 66(1-2), 189-195.

Ivašković, I. (2019a). The stakeholder-strategy relationship in non-profit basketball clubs. Economic Research-Ekonomska Istraživanja, 32(1), 1457-1475.

Ivašković, I. (2019b). Za kaj si prizadevajo neprofitni športni klubi?, Economic and business review, 21(spec.), 159-163.

Kaplan, R.S. (2001). Strategic performance measurement and management in nonprofit organizations, Nonprofit Management and Leadership, 11(3), 353-370.

Kern, A., Schwarzmann, M., and Wiedenegger, A. (2012). Measuring the efficiency of English Premier League football: A two-stage data envelopment analysis approach, Sport, Business and Management: An International Journal, 2(3), 177-195.

Kikulis, L., Slack, T., and Hinings, B. (1992). Institutionally specific design archetypes: a framework for understanding change in national sport organizations, International Review for Sociology of Sport, 27(4), 343-367.

Pološki-Vokić, N. (2003). Kreiranje višekriterijskog modela za analizu doprinosa managementa ljudskih potencijala uspješnosti poduzeća. Zagreb: Ekonomski fakultet.

Pološki-Vokić, N. (2004). Menađament ljudskih potencijala u velikim hrvatskim poduzećima, Ekonomski pregled, 55(5-6), 455-478.

Purcell, J., Kinnie, N., Hutchinson, S., Rayton, B., and Swart, J. (2003). Understanding the people and performance link: unlocking the black box. London: Chartered Institute for Personnel Development.

Schaufeli, W.B., Bakker, A.B., and Salanova, M. (2006). The measurement of work engagement with a short questionnaire: A cross-national study, Educational and Psychological Measurement, 66(4), 701-716.

Slack, T., and Hinings, B. (1994). Institutional pressures and isomorphic change: an empirical test, Organisation Studies, 15(6), 803-827.

Slack, T., (1997). Understanding sport organizations. Campaign: Human Kinetics.

Stevens, J.A., and Slack, T. (1998). Integrating social action and structural constraints: towards a more holistic explanation of organizational change, International Review for the Sociology of Sport, 33(2), 143-154.

Wright, P.M., and McMahan, C. (1992). Theoretical perspectives for strategic human resource management, Journal of Management, 18(2), 295-320.

Wright, P.M., Gardner, T.M., Moynihan, L.M., and Allen, M.R. (2005). The relationship between HR practices and firm performance: examining causal order, Personnel Psychology, 58(2), 409-446. 